\title{
A Critique on Feminist Research Methodology
}

\author{
Basharat Hussain ${ }^{1} \&$ Amir Zada Asad ${ }^{1}$ \\ ${ }^{1}$ Institute of Social Work, Sociology and Gender Studies, University of Peshawar, Pakistan \\ Correspondence: Basharat Hussain, Institute of Social Work, Sociology and Gender Studies, University of \\ Peshawar, Pakistan. E-mail: basharat04@yahoo.com
}

\author{
Received: September 12, 2012 Accepted: October 25, 2012 Online Published: November 29, 2012 \\ doi:10.5539/jpl.v5n4p202 \\ URL: http://dx.doi.org/10.5539/jpl.v5n4p202
}

\begin{abstract}
In almost all advanced countries of the world, the discourse about the existence or other wise of a feminist research methodology has been live at least for the last few decades. There are argument in favour of and against the existence of such a methodology to be called "Feminist" and its validity. This article criticizes the arguments made by feminist research methodology and maintains that these claims do not establish it as a coherent and cogent mode of inquiry distinct from other non-feminist research methods.
\end{abstract}

Keywords: feminist research, gender, women's empowerment, qualitative research, women experiences

\section{Introduction}

Feminism refers to the belief and claim that women should have the same rights, powers and opportunities as men. Feminist approach argues that women suffer more than men, are more poor than men and are discriminated in all welfare policies. Based on these assumptions feminists argue that women are not truly represented in studies and researches and are pursuing a distinct methodology of research they call it 'Feminist'. They claim to have specialized research methods and techniques but the opponent say these methods of research already existed and were in vogue and have nothing to do with feminists.

The feminists have long been trying to answer the question of 'what constitutes feminist social research?' They believe that 'there is a distinctively feminist mode of inquiry' (Maynard, 1994:10). The argument is made on the basis of certain characteristics which are claimed to be the main features of feminist research distinct from traditional social science research; researching on women issues and focusing on gender relations. In other words, a feminist research is carried out by a woman and drawing on the experience of women living in a world where they are subordinate to men. Many writers have distinguished feminist research from others on four distinct grounds which include focusing on gender relations, the validity of personal experience as against conventional emphasize on scientific method; rejecting hierarchy in research relationship between the researcher and the researched; and the adoption of emancipation of women as the goal of research.

Some writers (for example Hammersley, 1992) have challenged the foundations of the feminist methodology. Hammersley (1992) criticized the basic components on which feminists laid their foundations and concluded that:

The arguments in support of a feminist methodology do not establish it as a coherent and cogent alternative to non-feminist research. Many of the ideas on which feminists methodologists draw are also to be found in the non-feminist literature. (Hammersley, 1992:202)

However there is an overwhelming recognition that the feminist approach has brought substantial gains to the development of social research through the positive and creative production of knowledge and should not be undermined (Ramazanoglu, 1992). This article highlights the common features that constitute feminist research. It also examines Hamersley's critique and rejection of feminist method.

\section{Is There a Feminist Method?}

There is no consensus over the basic foundation of what constitute a feminist research. The available literature seems to suggest that many feminist authors have draw upon certain components as defining characteristics of feminist research. Maguire (1987:74) for example argued that feminist research consists of "no single set of agreed upon research guidelines or methods. Nor have feminists agreed upon one definition of feminist research". Some scholars have questioned the idea of having a feminist methodology at all (for example, Hammersley, 
1992); others have preferred instead to focus on what feminist research methodology actually includes - a way of dealing with the problem (Rheinharz, 1992). Rheinharz's view is that feminists have adopted some of the existing methods and also have developed new ones as well so that feminist research practices must be known as a plurality, that is, a perspective that uses several methodologies.

Kelly has argued that feminist methodology can be differentiated from others on the basis of nature of questions, the position of the researcher and the purpose of the research (Maynard, 1994). Furthermore, Roslyne Bologh, a US sociologist writes that

The question of difference is one with the question of identity. It is becoming the critical question for feminist theorizing in all the disciplines including social science research methods as feminists begin to question and challenge the implicit male perspective of the dominant paradigms, methodological strictures, and theoretical assumptions of the various disciplines (Reinharz, 1992: 3)

It is argued that feminist research is exclusively feminist because it is the feminist beliefs, motives, concerns and knowledge that act as the guiding framework to the whole research process. The methodology of feminist research differs from that of traditional social science researches on the basis of three reasons. First, feminist research explores and challenges the power imbalance between the researcher and the researched. Second, the feminist research is politically driven and has a sense of purpose and has an important role in removing the social inequalities. And finally, it asks for the experiences of women to guide the whole research process (Landman, 2006). Feminist methodology is mainly concerned about the way knowledge is produced about the social life and how it can be connected to the social realities of women. Similar claims were made by Sandra Harding when she stated that studying and knowing the perspectives of women, accepting the researcher as part of the research subject and appreciating the beliefs of the researcher guides the feminist research process. She argued that "they can be thought of as methodological features because they show us how to apply the general structure of scientific theory to research on women and gender" (Harding, 1987: 9). The following section will discuss in-depth the defining features of feminist research.

\subsection{Focus on Gender}

One of the key points of feminist research is its central concern with gender. The belief that the positions and powers of men and women are different in this social world, therefore this factor plays an important role in the research process. The conventional social science is considered as largely an expression of men which represent the male dominance voice in the patriarchal society (Smith, 1987).

The knowledge about women's lives and experiences are either absent or has been constructed by men from their own perspective. The traditional social research has investigated men's social world and the areas which are of interest to them. The experiences of women in public places are consciously made invisible or are produced from male perspective. The exclusion of women's voices and experiences in the production of knowledge are matter of concern for the feminist researchers.

Lather (1988) argued that the main purpose of the feminist research is to overcome the invisibility and distortion of female experience. It further argues that the concerns, perspectives and experiences of women provide the base of feminist research. Issues which are of interest to women provides the starting point for conducting research which embodies the experiences of women in the real world by using their own interpretation and using their own language. Feminist research studies women's lives focusing on their views and experiences which had previously been ignored by the social science researches. Traditionally, Maguire (1987) argued the concepts of objectivity, knowledge and reasons of the social world were produced by men and have become the dominant and objective view of the social world. Feminists argue that such analysis ignores gender differences and experiences and that conventional social science is male biased. As Hammersley (1992) argued;

\section{"Since gender difference structure person experience and belief, and given male dominance in society generally, conventional social science is primarily an expression of the experience of men presented as if it were human experience" (Hammersley, 1992: 187).}

Hammersley (1992) admitted the influence of feminist method which has increased research on gender related issues, which was previously ignored if compared to class and ethnicity. However, he questioned the primacy of feminist methodology. He argued that privileging the inevitable efforts and significance of gender is to ignore the other important aspects of the phenomenon under study. It does not seem to suggest that gender is not an important variable; however, gender should not be given any pre-established preference over other variables (Hammersley, 1992).

One of the problems for Hammersley (1992) is that feminists study only women. He argued that the lives of both 
men and women are so closely related that it is impossible to study one without others. Studying women's experiences only would mean ignoring the social world that actually produces these experiences.

Hammersley's (1992) work was strongly criticised by feminist writers. Gelsthorpe (1992) for example argued that Hammersley was wrong to assign the word 'gender' to women only. In contrast, gender is a wider term which refers to women's relationship to men and examination of the dominant masculine social world from women's perspective (Stanley and Wise, 1983).

\subsection{The Validity of Personal Experience against Scientific Method}

The second distinctive feature of feminist research is its focus on the validity of personal experience as against the scientific method. Du Bois (1983:108-10) argued that the central agenda of feminist is to address the problems of women and of their experiences in their own way and to create theory which is grounded in the real life experience by using the language of women. The purpose of research must be the identification of actual facts without any external influences (Hammersley, 1992).

Feminist researchers argue that women are the symbols of oppression being forced to fulfill the demands of their oppressors. These are the women who have experienced the oppression on their own psyche and bodies and are in better position to describe how exploitation and oppression would feel to the victims. Men usually do not have the practical knowledge of such experience and therefore lack sociological imagination of such exploitation. They also lack empathy and the ability to identify and understand the oppression and exploitation of women (Mies, 1983).

For feminist researchers, access to the truth about the social world is often guided by the women's experience that is not available to men. It is the belief of feminist researchers that personal experiences cannot be invalidated or nullified. Personal experiences are something which are felt and these experiences and feeling are real for women going through it (Stanley and Wise, 1983).

Feminist researchers believed that feminism has a distinct method of conducting social research. They generally refer to the qualitative approach in understanding women's problems and their lives. In contrast, the quantitative approach, especially the survey and questionnaire methods, is considered as a 'masculine' mode of working (Maynard, 1994). The feminist argument is based on the premise that the qualitative method gives more space to women to express their experience than the quantitative method. It is argued that structured methods lack the personal and social character of the research process and often impose the rules of the uninvolved researcher (Reinharz, 1992).

The feminists argue that quantification of actors lives 'distort rather than reflect actor's meanings' (Maynard, 1994:11). In addition, this method is unable to cover the in-depth feeling and understanding of people's lives. For feminists, researches which employ the pre-coded or closed - ended questions are very narrow in scope and such methods cannot understand properly the lives of women in the social world (Maynard, 1994). Such researches based on common-sense and a priori limited conception is unable to explore and investigate the realities of women's lives. Feminist argue that many aspects of women's lives which cannot be pre-defined or presume in advance like the traditional social science researches do. The feminist approach rejects the imposition of externally defined structures in understanding women's lives (Maynard, 1994).

Feminist researchers consider objectivity and neutrality as a masculine perspective in order to exercise power and control. Objectivity for feminists is an excuse being used for power relationship which treat women as mere objects and keep them in subordinate position by men. Feminist strongly criticized those who object the significance of personal experience and do not consider it as valid and true (Stanley and Wise, 1983)

Hammersley (1992) objected to the feminists claim and argued that reliance on experience over method is not distinctive to feminists. It is the common feature of the qualitative methodology. Hammersley (1992) argued that there is no single and direct way to access the truth. The knowledge about the realities of life can be gathered through different means. We should not emphasize on the use of either experience or method; these are two indispensible ways of collecting information in social science researches. Both methods have their own important place in social science researches and should be used in order to remove the weakness of individual research tool. Hammersley (1992) argued that method in an important element in the research activity. It reveals how the research was organized and conducted. It leaves the research open for scrutiny, discussion and for improvement.

Rejecting method would pose the risk of treating some of the experiences or assumptions of the researchers or participants beyond questions where these require proper scrutiny (Hammersley, 1992). In some situations, he argued that the unstructured methods would give more in-depth understanding of the situation than a structured 
method. However, it is a mistake to argue, as many feminists do that unstructured methods are appropriate to all purposes (Hammersley, 1992). In response, Williams (1993) argued that Hamersley's assessment of feminist methodology was conceptually too narrow. He added that feminists do not consider experience and method as conflicting; they are rather complementary.

\subsection{Rejecting Hierarchy in Research Relationship}

Feminists are critical about the way the sociological researches gather data. Oakley (1981) for example argued that a typical non-structured interview would not include pre-coded questions; it however cannot preclude the emotional detachment of researcher from those being researched and in controlling the situation. The researcher acts as a 'sponge' soaking up of information, whereas the subjects are 'passive givers of information' (Maynard, 1994:15). The feminists reject this power hierarchy between the researcher and the researched. They have argued that the research process should not be mere a means of collecting data; it should rather be a mean of sharing information with the personal involvement of the researcher in the research setting. Hammersley (1992:190) therefore suggested that feminists reject hierarchy on three points. First on the ethical grounds which means that feminist consider hierarchical relationship in the research process as unethical. It is believed that only non-hierarchical relationship can best reveals the true realities of women's lives. Second point is on methodology. It is feminist believe that the truth can only be discovered through establishing authentic relationships with the research participants. Feminist believe that structured hierarchical relationship will distort the data gathering process. And finally, if the research is to be effective in consciousness-raising, then it is important to engage the respondents into the research process (Hammersley, 1992)

Furthermore, Stanley and Wise (1983) also rejected the hierarchical relationship between the researcher and the research participants and argued that it treat people as mere research objects available to the researcher to conduct research on. Morally, the treatment of people as objects (research object or sex object) is unjustifiable.

Feminist are concern about ensuring the accuracy of the information that depicts the lives and experiences of women. It is suggested that the researcher is required to take the finalized information back to the research participants for its verification because they are the real owner and experts of their personal life experiences. It is a known fact that within the traditional social science researches, the whole research process is owned by the researcher. Feminist research tries to restructure and remove the inequalities with respect to the notion of ownership of knowledge produced in the research process (Wolf, 1996). Feminist research tries to keep the authenticity and originality of the way participants give meaning to their life experiences which is a part of the efforts for changing the power inequalities in feminist research.

Hammersley (1992) argued that it is difficult to avoid the hierarchical relationship in the research process. Practically it is impossible for the researcher to interview anyone and whenever he wants. There has to be some control over some part of the research process. Research is actually a very small and marginalized part of people's lives. In addition, he stated that there are a number of women holding powerful positions and feminists cannot avoid hierarchical relationships in dealing with them.

\subsection{Goal of the Research}

Feminists argue that research for the sake of research is insufficient. The change of status quo must be the starting point of the scientific inquiry (Mies, 1983). Instead of being a tool to uphold the dominant masculine views of the world, feminist believe that research must serve the interests of women. This is not to suggest that feminist research must be an abstract free from proper investigation but instead must have the commitment for bringing social change.

Feminist research are not meant for simply seeking and presenting the data and information, it is rather aims to provide recommendations for policy change with the researcher being a part of the collective efforts involved in political activity. Therefore, feminist research is not about women but research for women to be used in changing their sexist society. The commitment of the feminist research is based on the underlying motivation that research and action cannot be separated in the research process.

In part, a commitment to bring societal changes entails a commitment to the research participants. The active involvement of women in the research process provide them opportunity and space to pose questions and critically assess their personal life experiences. It also helps in identification of the connections and links between events in their lives and connecting them to the social world. The identification and understanding of personal experience and connecting them with the social relations is important because it facilitate the analysis of personal experiences and transformation. The best way of empowering women is education and knowledge about their issues and the assertion that our personal life experiences are just a part of the larger social structure. 
Hammersley (1992) argued that for many feminists, the primary goal of research is not the production of valid knowledge. For them, emancipation of women is more important to be achieved through the research process. In addition, Mies (1983) stated that the research which until now has been used as instrument for the dominant and the legitimatization of elite powers, must now serve the interests of the exploited and dominated groups, especially women.

Hammersley (1992) criticized the notion that empowerment of women should be the sole goal of feminist research. He argued that in today's world, there are various sources of oppression like race, ethnicity, sexuality and class; it is therefore extremely difficult to build a single model of oppression. For example how can we reduce racial oppression to class oppression? Moreover, we will find many people, who would be classified both as oppressed and oppressors at the same time. For example, a black woman living in a Western society would be classified as one of the oppressors when the focus is on international exploitation of different societies (Hammersley, 1992).

\section{Conclusions}

Feminist research is concerned with studying the issues facing women at its starting point. It seeks to search and explore the social dynamics and relationships in patriarchal society from women's perspective. Feminist research is not just adding women to the research equation or engaging women as researchers. Feminist research takes into account women's viewpoint as the base of the research. Such research proceeds from a standpoint that values women's experience, needs and ideas of the social world. Feminist research also aims at bringing changes and eliminating gender imbalances in the world. It would be wrong to suggest that feminist researchers consider feminist research as one unified research methodology. There is no agreement on what feminist research is and should be. Feminist researchers have put forward diverse methods which help in facilitating diverse knowledge about social phenomenon. Feminist reject objectivity and talk about subjectivity and the partial truth of the social world.

\section{References}

Du Bois, B. (1983). Passionate Scholarship: notes on values, knowing and method in feminist social research. In Bowles, G., \& Duelli, K. R. (Eds.), Theories of Women's Studies. London: Routledge and Kegan Paul.

Gelsthorpe, L. (1992). Response to Martyne Hamersley's Paper on Feminist Methodology. Sociology, 26(2), 213-218. http://dx.doi.org/10.1177/0038038592026002004

Hammersley, M. (1992). On Feminist Methodology. Sociology, 26(2), 187-206. http://dx.doi.org/10.1177/0038038592026002002

Harding, S. (1987). Is there a Feminist Method? In Harding, S. (Ed.), Feminism and Methodology. Bloomington: Indiana University Press.

Landman, M. (2006). Getting Quality in Qualitative Research: A Short Introduction to Feminist Methodology and Methods. Proceeding of the Nutrition Society, 65, 429-433. http://dx.doi.org/10.1079/PNS2006518

Lather, P. (1988). Feminist Perspective on Empowering Research Methodologies. Women's Studies International Forum, 11(6), 569-581. http://dx.doi.org/10.1016/0277-5395(88)90110-0

Maguire, P. (1987). Doing Participatory Research: A Feminist Approach. Massachusetts: University of Massachusetts.

Maynard, M. (1994). Methods, Practice and Epistemology: The Debate about Feminism and Research. In Maynard, M., \& Purvis, J. (Eds.), Researching Women's Lives from a Feminist Perspective. London: Taylor and Francis.

Mies, M. (1983). Towards a Methodology for Feminist Research. In Bowles, \& Duelli, K. (Eds.), Theories of women studies. London: Routledge and Kegan Paul.

Oakley, A. (1981). Interviewing Women: a contradiction in terms. In Roberts (Ed.), Doing Feminist Research. London: Routledge and Kegan Paul.

Ramazanoglu, C. (1992). On Feminist Methodology: Male Reason versus Female Empowerment. Sociology, 26(2), 207-212. http://dx.doi.org/10.1177/0038038592026002003

Reinharz, S. (1992). Feminist Methods in Social Research. New York: Oxford University Press.

Smith, D. E. (1987). The Everyday World as Problematic: a feminist sociology. Milton Keynes: Open University Press. 
Stanley, L. \& Wise, S. (1983). Breaking out: Feminist consciousness and feminist research. London: Routledge Kegan Paul.

Williams, A. (1993). Diversity and Agreement in Feminist Ethnography. Sociology, 27(4), 575-589. http://dx.doi.org/10.1177/0038038593027004002

Wolf, D. L. (1996). Situating Feminist Dilemmas in Fieldwork. In D. L. Wolf (Ed.), In Feminist Dilemmas in Fieldwork (pp. 1-55). Colorado: Westview Press. 